\title{
Trace fossils and rhizoliths as a tool for sedimentological and palaeoenvironmental analysis of ancient continental evaporite successions
}

\author{
J.P. Rodríguez-Aranda*, J.P. Calvo \\ Dep. de Petrología y Geoquímica, Facultad de C. Geológicas, Universidad Complutense, 28040 Madrid, Spain
}

\begin{abstract}
Recognition of evaporite formations from continental Tertiary basins of Spain provides evidence that trace fossils (including rhizoliths) can be abundant in some saline lake systems and their study helps in palaeoenvironmental interpretation of ancient continental evaporite sequences. Six main types of trace fossils have been distinguished and include: (1) networks of small rhizoliths; (2) large rhizoliths; (3) tangle-patterned small burrows; (4) isolated large burrows; (5) L-shaped traces; and (6) vertebrate tracks. Rhizoliths were related to both marginal areas of hypersaline lakes and lakes of moderately high saline waters. In these settings, pedoturbation resulted from colonization by grasses and bushes of distinct lake subenvironments. The activity of burrowing invertebrate faunas was especially intense in lakes of moderately concentrated brines from which gypsum was the main evaporite mineral deposited. A specific gypsum lithofacies ('bioturbated gypsum deposits') forming thick, massive beds has a widespread occurrence in many of the basins. Tangle-patterned small burrows and minor isolated large burrows constitute the typical trace fossil types within the gypsum. The traces are interpreted as having been caused by burrowing insect larvae, probably chironomids, coleopterans and annelids. The behaviour of these organisms in recent lake environments yields information about the salinity range of lake waters from which gypsum precipitated. Concentration values averaging 100-150 g/l may be thus deduced though some organisms involved in the formation of the traces can tolerate higher salinities. The combined analysis of lithofacies and trace fossils from the lacustrine evaporite sequences contributes to the study of distinct saline lake subenvironments as well as changes in the sedimentary evolution of the lake systems. Consequently, trace fossils can provide valuable insight for palaeoenvironmental analysis of at least some evaporite formations that accumulated in continental settings.
\end{abstract}

Keywords: trace fossils; ichnofabrics; evaporite environments; gypsum; continental formations; palaeolimnology

\section{Introduction}

Pervasive diagenesis commonly modifies the syndepositional mineralogical and textural features of

\footnotetext{
* Corresponding author. Tel.: C34-394-4907; Fax: C34-3942535.
}

evaporites. This may render sedimentological and palaeoenvironmental interpretation difficult, particularly in weathered outcrops where no borehole material is available. Further difficulty is experienced through the general lack of fossil remains and by the lack of recent counterparts.

As in marine evaporite environments, sediments 
accumulated in saline lakes usually contain very scarce remains resulting from fossilization of hard parts of organisms, though in rare cases ostracod shells (Chivas et al., 1986; Palacios-Fest et al., 1994) and athalassian foraminifers and gastropods (Anadón, 1989; Plaziat, 1989) have been found. The scarcity of fossils in saline lake successions is in contrast with the widespread presence of life in recent salt lakes (Friedman and Krumbein, 1985; Hammer, 1986), probably because of the low fossilization potential of the organisms living in this environment. Thus, whereas some organic structures such as cyanobacterial mats are commonly preserved, macrophytes, phyto- and zoobenthic species, as well as the profuse activity of microbial organisms that commonly results in sulphate-reduction facies (Rouchy et al., 1986) are hardly recorded as fossil remains. Documentation of the relations between organisms and sediments accumulated in saline lakes has been improved by thorough observations of these settings in western USA, Canada, Australia, Spain, Israel and other countries (Burne et al., 1980; Spencer, 1982; Gerdes et al., 1985; Bauld, 1986; Calvo and Iborra, 1986; Montes and Martino, 1987; De Deckker, 1988; Last, 1989; Williams et al., 1990). Despite the great abundance of living forms in recent saline lakes, ancient evaporites rarely record traces of such a profuse development, which can be explained by their low preservation potential.

On the other hand, trace fossils have been sparsely recognized in ancient continental evaporite sequences (Van Dijk et al., 1978; Truc, 1978, 1980; Salvany et al., 1994), which is in contrast with the relatively frequent occurrences of trace fossils in other nonmarine sediments (Chamberlain, 1975; Tevesz and McCall, 1982; Ekdale et al., 1984; Retallack, 1990; Gierlowski-Kordesch, 1991; Pemberton et al., 1992; Buatois and Mángano, 1995; Bromley, 1996). Our experience in continental evaporite formations, especially of Tertiary age, of a number of basins in Spain allows us to highlight the importance of trace fossils as a tool in sedimentological and palaeoenvironmental analysis of ancient saline lake systems. In this paper, we show several examples of trace fossil-rich gypsum deposits that constitute a substantial part of the sedimentary record of the basins. A typology of the several trace fossils is established and their use as palaeoenvironmental indicators is discussed.

\section{Trace fossil occurrences in Tertiary evaporite lake systems of Spain}

During the Tertiary, a wide development of continental lake basins is recorded in Spain (Fig. 1). The formation of the basins was mainly related to the Alpine orogeny and took place in several distinct tectonic settings, such as intraplate areas (Madrid Basin), foreland regions linked to the Pyrenean thrust (Ebro, Duero), and basins resulting from major rifting in Early Miocene times (lacustrine basins of northeastern Spain) (Anadón et al., 1989; Friend and Dabrio, 1996).

The lacustrine sedimentary infilling of the basins was varied and evaporite facies are present in many of them. The evaporite deposits comprise both gypsum and other more soluble salts, i.e. anhydrite, halite, glauberite and thenardite, which are commonly associated with mudstone, marlstone, and carbonate facies. The thickness of the evaporite formations ranges from several tens of metres to, as observed in the Madrid and Ebro basins, thousands of metres (Calvo et al., 1989; Ortí and Salvany, 1990; Alonso-Zarza et al., 1992), the latter case implying that the evaporite deposits form the whole succession accumulated in central parts of the basins throughout most of the Tertiary.

The occurrence of trace fossils within the evaporite formations has been mainly recognized in gypsum beds and in sequences where gypsum, locally glauberite and/or anhydrite, is associated with mudstone and carbonate deposits. Trace fossils have been locally indicated in evaporite sequences of the Duero Basin (Mediavilla, 1986; Corrochano and Armenteros, 1989), Loranca Basin (also named Intermediate Depression) (Torres and Zapata, 1986; Arribas et al., 1991), Calatayud and Teruel basins (Ortí, 1987; Anadón et al., 1995), Madrid Basin (Rodríguez-Aranda, 1992; Sanz et al., 1994), Ebro Basin (Salvany et al., 1994), and Fortuna and ArchenaMula basins (Playa, 1995). Besides these occurrences in Spain, trace fossils associated with gypsum have also been recognized in Tertiary basins of France, in particular the Mormoiron-Pernez Basin (Truc, 1978, 1980) as well as in continental intercalations within the evaporite formations of the Paris Basin (J.M. Rouchy and M. Blanc-Valleron, pers. commun., 1991). Although no systematic analysis 


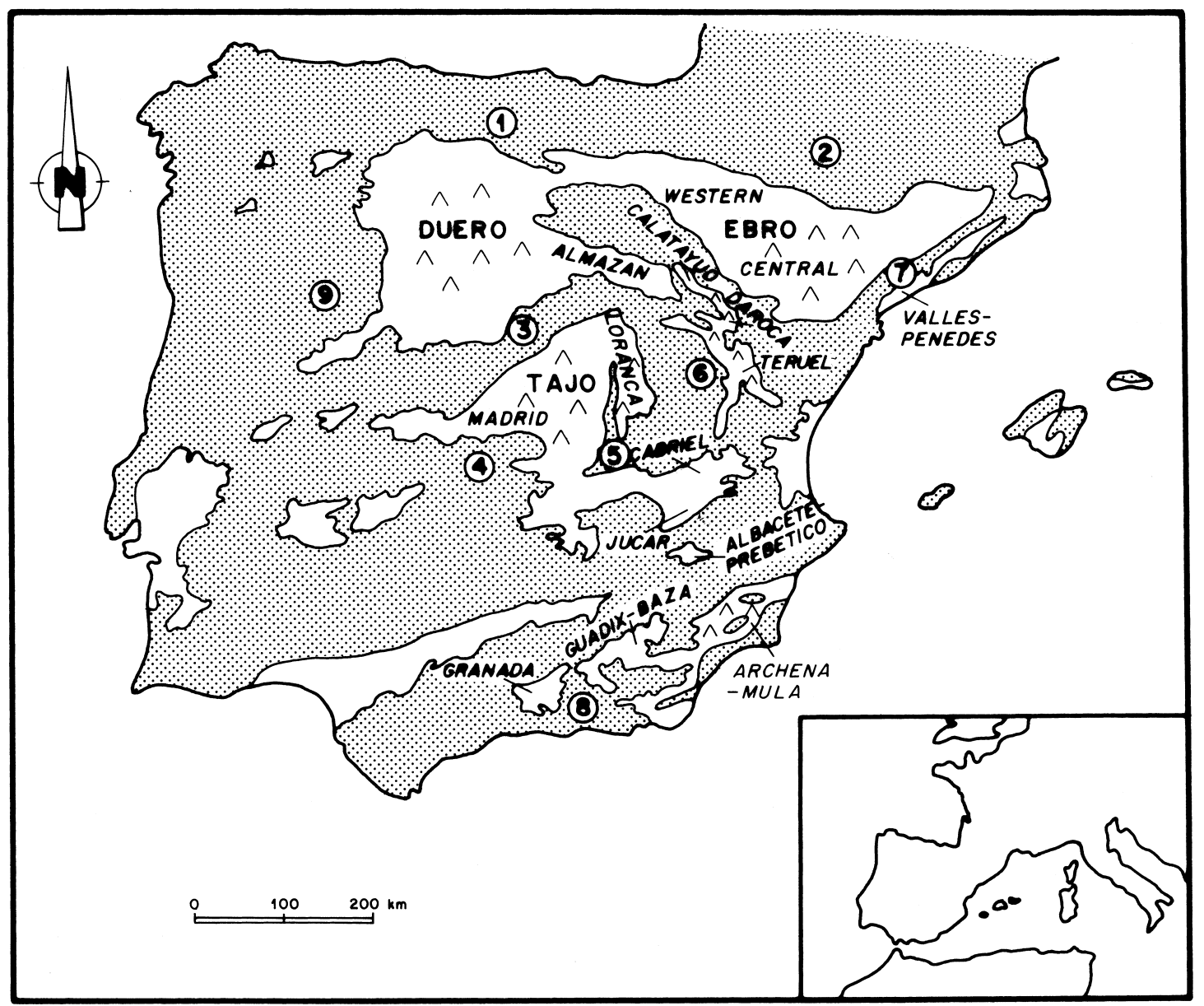

Fig. 1. Location of the main Tertiary basins in Spain. Larger continental Tertiary basins are indicated with large capital letters whereas the several subbasins or smaller basins are written in italics. Continental basins cited in the paper are indicated with the symbol for evaporites. Encircled numbers show the major structural chains bounding the basins: 1 D Cantabrian Range; 2 D Pyrenees; 3 D Central Systems; 4 D Toledo Mountains; 5 D Altomira Range; 6 D Iberian Range; 7 D Catalan Coastal Range; 8 D Hesperic Massif.

has yet been carried out, most of the gypsum deposits containing trace fossils in the basins seem to be upper Oligocene and Miocene in age.

Trace fossils constitute a very prominent feature of a specific gypsum facies that almost exclusively forms the evaporite lake deposits of several basins, for instance the Teruel Basin and the Intermediate Depression, or represents the most typical facies of some lithostratigraphic units of the basins. This is the case of the Miocene Intermediate Unit of the Madrid Basin, where the strongly burrowed gypsum deposits occur in metre-thick, massive beds alternating with mudstone and/or carbonate deposits (Rodríguez-Aranda, 1995). In all examples observed by the authors in the several basins, the gypsum beds are characteristically massive and display a tabular geometry (Fig. 2). The bed colours are cream to greenish grey and thickness ranges from a few metres to more than $10 \mathrm{~m}$, although local bed partitioning often can be observed within the thickest gypsum deposits. The facies consists of strongly bioturbated lenticular gypsum (named below the 'bioturbated gypsum 


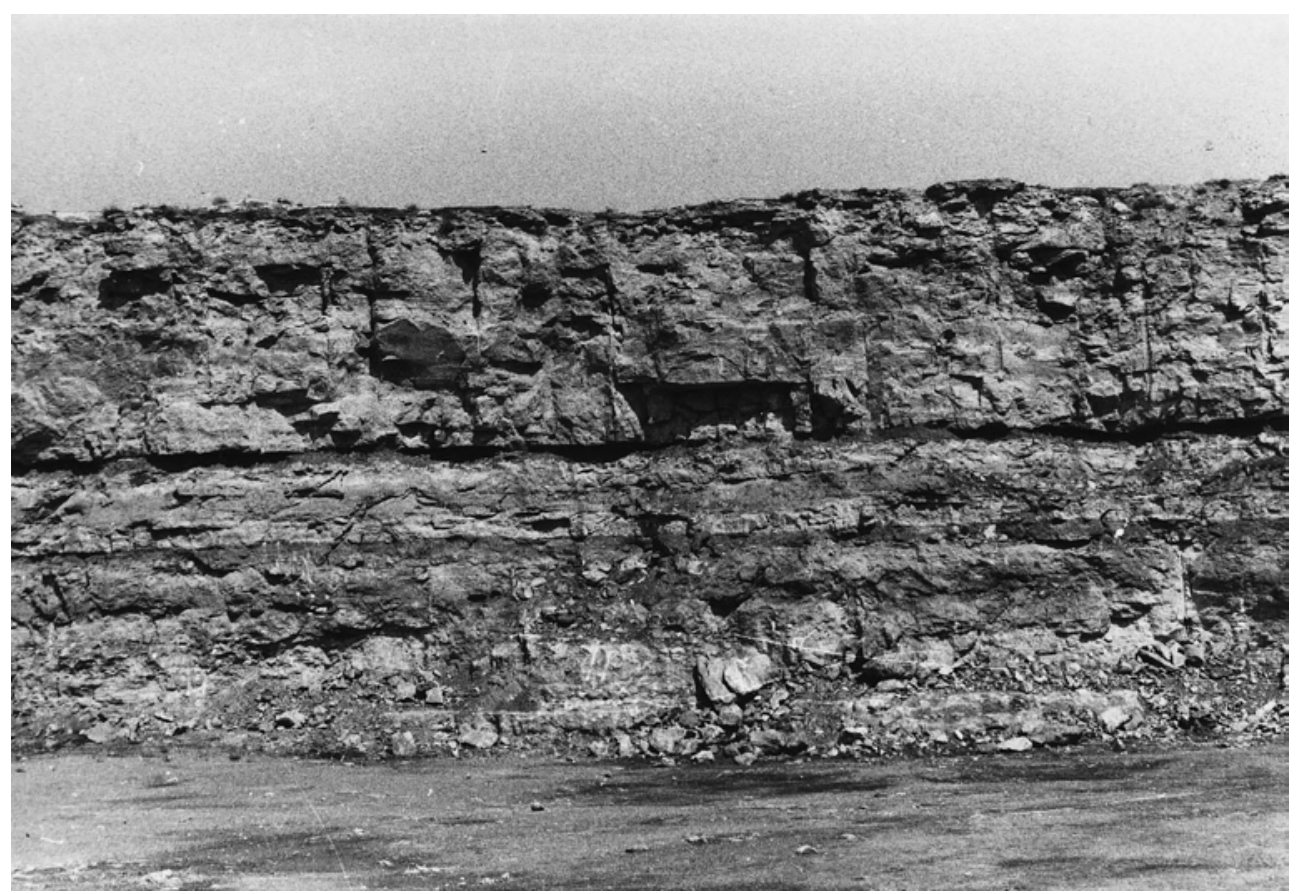

Fig. 2. General view of an outcrop of bioturbated gypsum deposits (upper part of the section) showing the characteristic tabular bed geometry and massive internal structure of this gypsum facies. The bioturbated gypsum overlies alternating mudstone and nodular gypsum deposits. Almoguera section, Lower Miocene, Madrid Basin. The height of the outcrop is $7 \mathrm{~m}$.

deposits') and the trace fossils, owing to extensive burrowing by animals, comprise mainly the types 3 and 4 as referred to in a later section. The syndepositional gypsum fabrics consist of: (1) unimodal microto mesolenticular gypsum composed of untwinned, 0.025-0.3 mm long gypsum lenses that commonly display syntaxial overgrowth. Clay and/or micrite matrix is absent or does not exceed $10 \%$ of the gypsum fabric; (2) bimodal, meso- to macrolenticular gypsum, similar to the previous fabric but including a population of larger, $0.5-5 \mathrm{~mm}$ long lenses of intrasedimentary displacive and/or poikilotopic gypsum scattered within the finer-grained lenticular mosaic.

Besides these two main types of gypsum fabrics, the bioturbated gypsum deposits are locally formed of anhedral microcrystalline gypsum mosaics that show textural similarities with the 'settled' gypsum of Magee (1991). Both the lenticular and anhedral gypsum fabrics are interpreted to have been deposited under subaqueous conditions, thus their occurrence in the basins is indicative of rather permanent saline water bodies.
Other types of trace fossils, mainly related to roots, are present in beds formed of anhedral, 10-100 $\mu \mathrm{m}$ gypsum mosaics with gypsum micronodules that display features, e.g. pseudomorphs and ghosts of gypsum lenses, indicative of dissolution and further precipitation of previous syndepositional gypsum facies. Some gypsum crystals contain anhydrite inclusions. The transformation of the gypsum is interpreted to have been early diagenetic under subaerial exposure conditions (Rodríguez-Aranda, 1995).

In addition to these occurrences in chemically precipitated gypsum, trace fossils, mainly root casts, are also present in detrital gypsum deposits in which the sand- to silt-size gypsum grains were accumulated by reworking of either selenite crystals growing in very shallow lakes or gypsum crystals formed displacively in the saline mudflats (Sanz et al., 1994).

Finally, trace fossils, especially those related to bioturbation by roots, are recognized in mudstones and calcareous beds intercalated with the gypsum, glauberite, and anhydrite deposits.

An appraisal of the geographical distribution of the evaporite sequences containing abundant trace 
fossils in the Tertiary basins leads us to conclude that these deposits are common in three separate evaporite lake settings. The differentiation is made on the basis of the interpreted palaeogeography of the individual lakes throughout the sedimentary evolution of the basins:

(1) Large evaporite lake systems (thousands of square kilometres) that covered most of the surface of the basins, for instance the Madrid and Duero basins during the Middle Miocene and the Middle to Late Miocene, respectively. In both cases, gypsum is the dominant evaporite facies being accumulated under moderately high saline lake conditions.

(2) Small evaporite lake systems (hundreds of square kilometres) developed in basins of reduced extent; examples are furnished by the upper Oligocene to lower Miocene of the Intermediate Depression and the upper Miocene of the Teruel Basin. The evaporite facies are predominantly composed of gypsum, that is also interpreted to have been deposited in moderately saline lakes.

(3) Evaporite lakes of reduced extent (hundreds of square kilometres) adjacent to larger hypersaline lakes. This is the case of the Madrid and Ebro basins during the Early Miocene (Ortí et al., 1984). The dominant gypsum facies accumulated in lakes located in the peripheries of the basins, in contrast to the halite, anhydrite, and sodium sulphate deposits which characterize sedimentation from highly concentrated brines in central areas of the basins.

\section{Trace fossil types}

Six main types of trace fossils and rhizoliths have been distinguished in the Tertiary continental evaporite formations. In this classification we include traces related to plant root penetration that are preserved as casts or rhizoliths (Sarjeant, 1975; Bromley, 1996). The criteria used for the classification follow those of Simpson (1975); Frey and Pemberton (1984); García-Ramos et al. (1989) and Bromley (1996), and include: (1) density or degree of bioturbation, ranging from isolated traces to densely bioturbated fabrics; (2) trace geometries; (3) orientation and distribution of the traces within the sedimentary bed; (4) size, from microscopic to metric; (5) internal structure and infill pattern of the traces, with dif- ferentiation between active (backfill, meniscus) or passive (gravitationally deposited internal sediment and chemical cementation) infill; and (6) lithofacies in which the traces are developed. On this basis, we have differentiated the following types of trace fossils and rhizoliths (Fig. 3).

\subsection{Type 1: networks of small rhizoliths}

\subsubsection{Description}

The density of bioturbation is moderate to high (Fig. 4A). The cylinder root tubes are dominantly vertical or slightly oblique to the bed surfaces and show downwards bifurcation so giving a branching appearance. The length range is $1-7 \mathrm{~cm}$ and diameters vary from 0.5 to $3 \mathrm{~mm}$. The infill of the tubes is passive and consists of massive, usually mottled, clay with variable amount of carbonate, occasionally cemented by mesocrystalline gypsum. Outside the tubes, there is a feebly cemented zone of carbonate which impregnates the surrounding sediment. The networks of small rhizoliths are mainly developed at the tops of reddish-brown and greenish mudstone beds that commonly contain nodules of secondary gypsum after anhydrite, though they also occur in gypsum-bearing marls and carbonates as well in gypsum deposits.

\subsubsection{Interpretation}

Both the small dimensions and the common high density of the bioturbation traces suggest they are rhizoliths associated with grass plants (Klappa, 1980; Retallack, 1990). According to Cohen (1982), the growth of the plants could take place either under vadose or phreatic conditions. This is corroborated by the fact the rhizoliths are developed in sediments accumulated in both oxidizing conditions (e.g. reddish-brown clays) or very shallow lacustrine marls and pond carbonates.

\subsection{Type 2: large rhizoliths}

\subsubsection{Description}

Density of bioturbation is moderate to low. The geometry of the traces is typically cylindrical, extending up to $1.5 \mathrm{~m}$ downwards from the bed surfaces. The external walls of the rhizoliths show small, millimetric protuberances (Fig. 4B). Branch- 


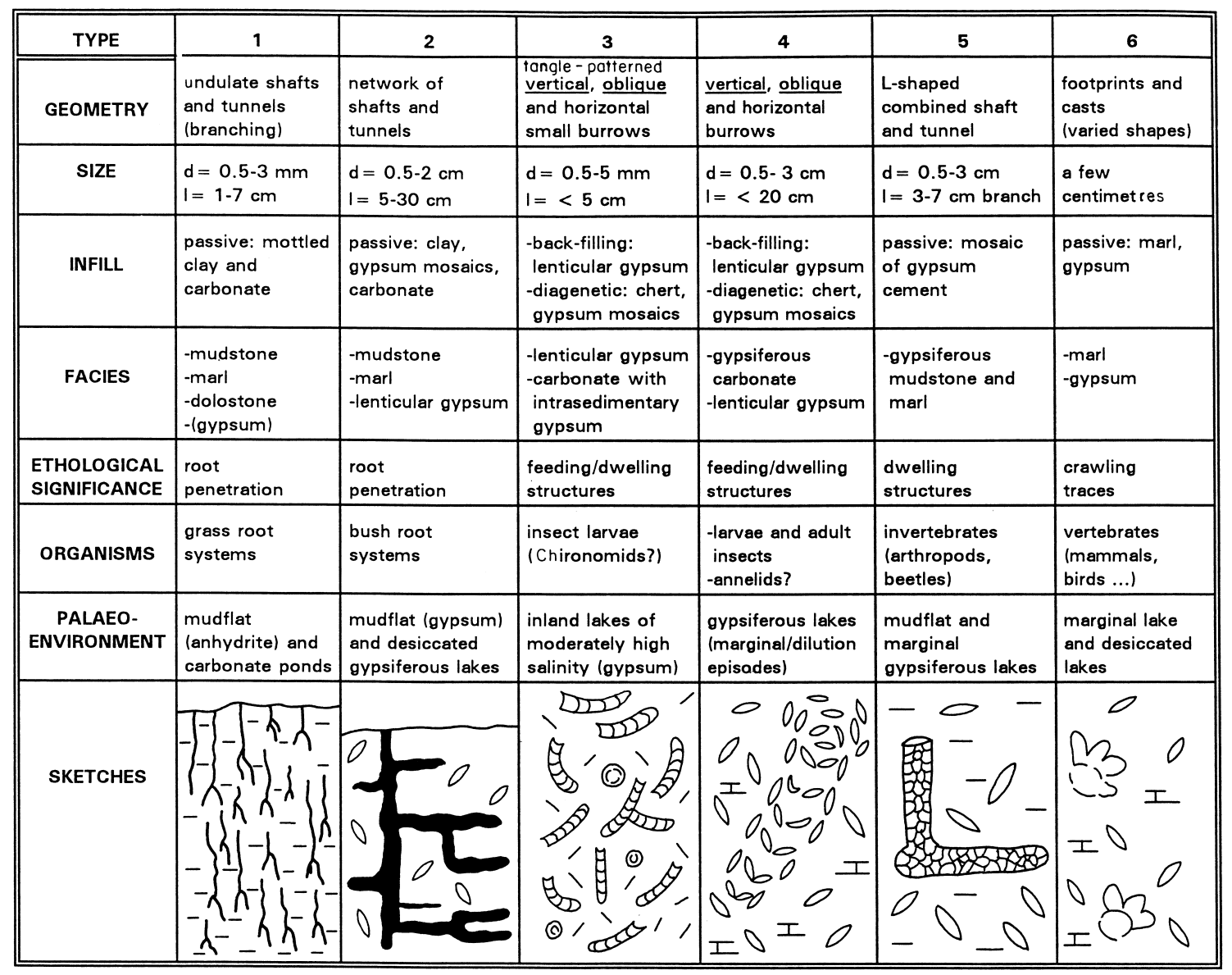

Fig. 3. Summary of the main features and interpretation of the trace fossil and rhizolith types recognized in continental evaporite formations from Tertiary basins in Spain. Sketches of the trace fossils and rhizoliths at the bottom are not to scale.

ing is common resulting in a pattern of shafts and perpendicular tunnels, seen to a maximum length of $30 \mathrm{~cm}$, that commonly approach laterally other rhizoliths developed in the same bed. In these cases, a network of apparently interconnected root casts is formed. Several networks of rhizoliths have been recognized in the same bed as a result of successive stages of plant colonization. The diameter of the rhizoliths range from 0.5 to $2 \mathrm{~cm}$. Local observation of rhizoliths reaching up to $20 \mathrm{~cm}$ in diameter is explained by the enlargement of tap root tubes in beds that underwent mid- to high-term karstification (Rodríguez-Aranda, 1995; Rodríguez-Aranda et al., 1996).
The infill of the tubes is passive and consists mainly of massive clay with variable amount of carbonate and scattered gypsum lenses. Where gypsum is present as an occasional root infill, it comprises micro- to meso crystalline, anhedral mosaics. Similarly to that observed for the type- 1 traces, these larger rhizoliths are usually present at the tops of mudstone, pond carbonate and, rarely, gypsum beds.

\subsubsection{Interpretation}

On the basis of their dimensions and geometries, the rhizoliths are interpreted to be associated with bush plants, probably growing in an arid or semi-arid setting (Sarjeant, 1975; Evenary et al., 1985). The 
pattern shown by root branches seems to be typical of growth in a vadose environment (Cohen, 1982). Their location at bedtops of variable lithology is indicative of sediment accumulation in distinct mudflat and evaporite lake subenvironments and suggests that the growth of the bushes was particularly favoured in periods of quite reduced sedimentation rates. This is especially clear in gypsum bedtops where the root casts were enlarged by karstification processes.

\subsection{Type 3: tangle-patterned small burrows}

\subsubsection{Description}

The density of bioturbation is commonly very high, the burrowed sediment exceeding $60 \%$ of the total bed volume. The burrows, displaying contorted or rarely straight morphologies, are tangled in all directions (Fig. 4C). The length of the individual burrows does not exceed $5 \mathrm{~cm}$ and diameters range from 0.5 to $5 \mathrm{~mm}$. They typically show cylindrical meniscate backfill structures composed of either micro- to mesolenticular gypsum (Fig. 4D) or micrite with abundant gypsum lenses. Locally the meniscate infill comprises laminae with different proportions of gypsum and carbonate as well as variations in length of the gypsum lenses. Faecal pellets (McCall and Tevesz, 1982; Pueyo, 1991) are commonly observed within the laminae. The burrows are usually delimited by lineations of gypsum lenses ('burrow-lining'; Fig. 4D) which are probably due to the reinforcement of the burrow walls by impregnation with mucus (Frey and Pemberton, 1984; D’Alessandro and Bromley, 1987). In cross-section, the burrows show a rather well-defined concentric arrangement of gypsum lenses and variable amount of micrite and/or clay (Fig. 4E). The meniscate backfill by lenticular gypsum may be diagenetically substituted by cementing gypsum mosaics or replaced by microcrystalline quartz (Arribas et al., 1991).

As aforementioned, this type of trace fossils occurs in sediments which consist typically of unimodal micro- to mesolenticular gypsum, bimodal mesolenticular gypsum, micrite with intrasedimentary gypsum lenses or, less commonly, anhedral microcrystalline gypsum. In the latter case, the burrows are not so easily recognized.

\subsubsection{Interpretation}

These trace fossils are interpreted as feeding and/or dwelling structures produced by subaquatic insect larvae that are tentatively attributed to Chironomidae. This interpretation is based on the similarities the traces show with bioturbation by insect larvae and chironomids described by Chamberlain (1975); Truc (1980); McCall and Tevesz (1982), and Frey and Pemberton (1984). Both geometry and size as well as the meniscate backfill pattern of the burrows are consistent with the attribution to Chironomidae [Walshe (1951) in Thienemann (1954)]. On the other hand, the great variability of the burrow sizes, which could reflect distinct stages of larval growth, are in agreement with this proposal. Moreover, chironomids are organic detrital feeders that can develop dense populations in environments permanently or episodically covered by water (Oliver, 1971; Fisher, 1982; De Deckker, 1988) with relatively high salinity (commonly 70-100 g/l, occasionally up to $170 \mathrm{~g} / \mathrm{l}$ ) (Paterson and Walker, 1974; Hammer, 1986; Williams et al., 1990; Pueyo, 1991). Occurrence of trace fossils produced by bioturbation by chironomids has been reported by Monty (1976); Anadó n and Zamarreño (1981), and Armenteros et al. (1986) from ancient carbonate sediments, the oldest occurrence corresponding to the Jurassic of Siberia, predating the higher proliferation of chironomids after Late Eocene times (Wooton, 1988). However, no description of more ancient gypsiferous sediments strongly bioturbated by these animals has been documented up to now.

\subsection{Type 4: isolated large burrows}

\subsubsection{Description}

The density of bioturbation is moderate to high. By contrast with the tangle-patterned small burrows, the large individual burrows can be clearly differentiated within the bioturbated beds (Fig. 5A). Their geometries vary from nearly straight to contorted, showing variable orientation, from vertical to oblique with respect to the bed surfaces. The maximum recorded length is $20 \mathrm{~cm}$ and diameters range from 0.5 to $3 \mathrm{~cm}$. The burrows show meniscate backfill structures, quite similar to trace fossils of type-3. Likewise, the sediment that infills the burrows is composed of lenticular gypsum and/or micrite, and 

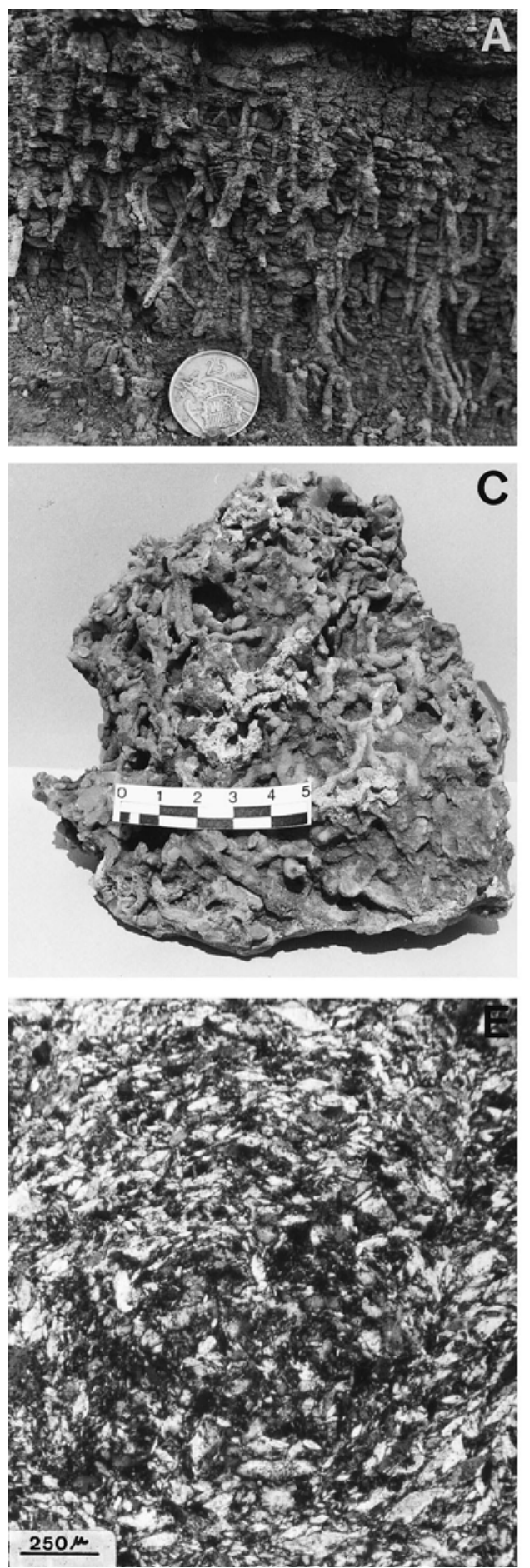

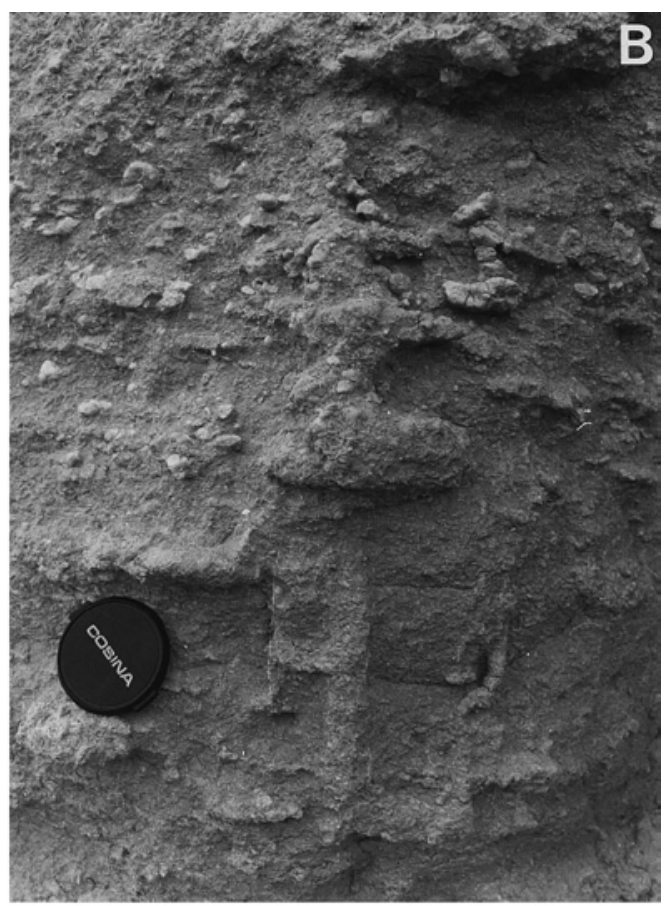

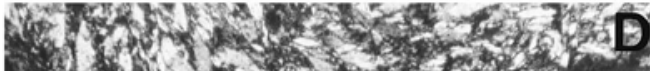

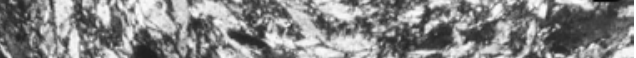

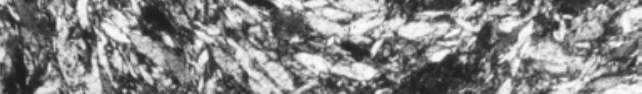

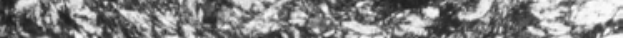

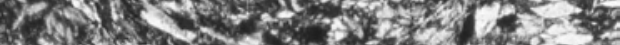

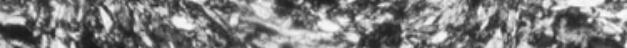

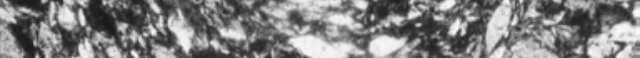

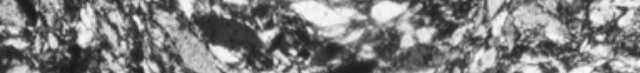

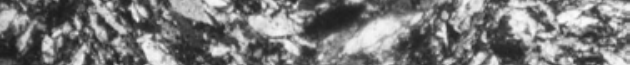

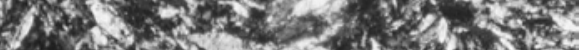

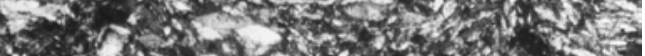

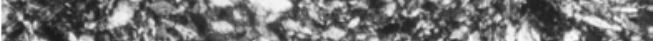

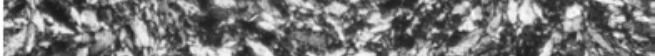

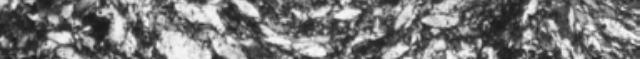

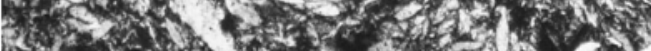

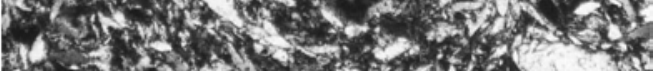

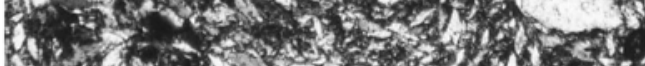

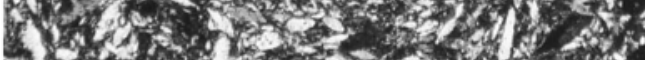

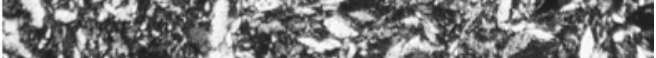

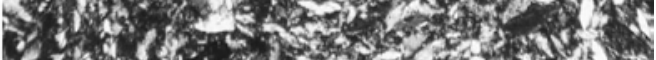
1. 5 (10.

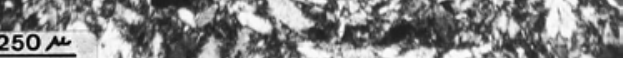



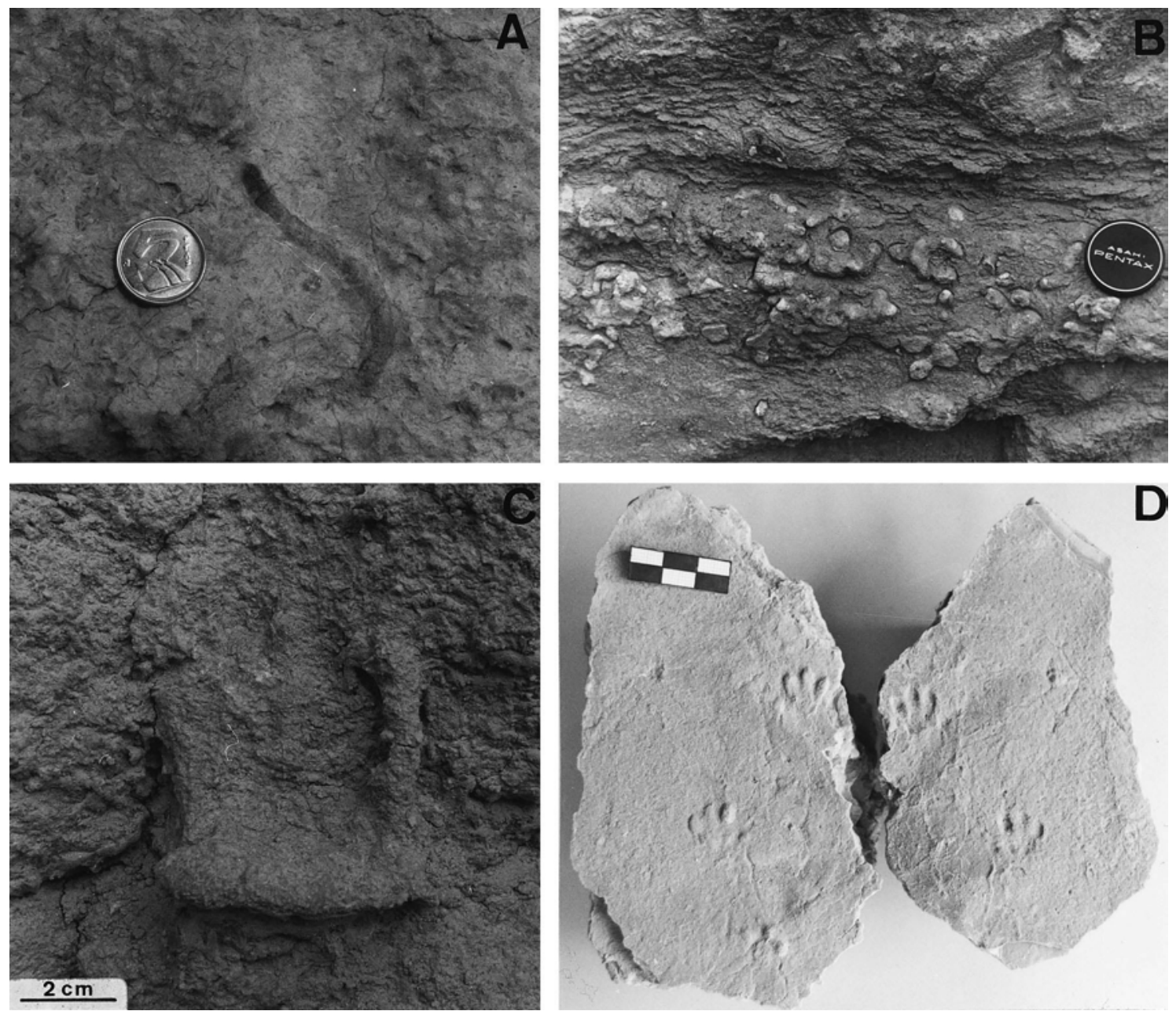

Fig. 5. (A) Close-up view of an isolated large burrow in lenticular gypsum beds. The coin for scale is $1.5 \mathrm{~cm}$ in diameter. (B) Isolated large burrows concentrated in a gypsiferous marlstone bed. The camera lens for scale is $7 \mathrm{~cm}$ in diameter. (C) Close-up view of a L-shaped trace developed in gypsiferous mudstone. The horizontal branch (tunnel) of the trace is slightly flattened due to compaction of the sediment. (D) Aspect of vertebrate tracks probably due to small hyaenids at the surface of a gypsiferous mudstone bed.

locally contains faecal pellets. The trace fossils are commonly observed in whitish green marlstone with intrasedimentary gypsum lenses and less frequently in unimodal or bimodal lenticular gypsum beds.
Contrary to the tangle-patterned small burrows, the isolated large burrows are usually associated with specific horizons of the carbonate or gypsum beds (Fig. 5B).

Fig. 4. (A) Close-up view of a network of small rhizoliths interpreted as grass roots that penetrated green mudstone deposits; coin for scale is $2.2 \mathrm{~cm}$ in diameter. (B) Large rhizolith included in marlstone and gypsum horizons. The vertical tap root bifurcates into several perpendicular branches. The camera lens is $7 \mathrm{~cm}$ in diameter. (C) Typical aspect of the tangle-patterned small burrows. In the picture, the morphology of the individual burrows is enhanced by silicification of the gypsum. (D) Photomicrograph of bioturbated gypsum showing the meniscate backfill characteristic of tangle-patterned small burrows. Oriented gypsum lenses at the edges of the burrow infill are probably related to the impregnation of the walls by mucus. (E) Photomicrograph of a cross-section of a small burrow in bioturbated gypsum deposits showing the concentric arrangement of the gypsum lenses. 


\subsubsection{Interpretation}

These trace fossils are interpreted as feeding and/or living structures produced by invertebrates, very likely arthropods (larvae or adult insects, coleoptera, ...) and/or annelids (Chamberlain, 1975; Retallack, 1990). Similar structures, though displaying a larger size, have been described as 'large oblique burrows' by Bromley and Asgaard (1979) who interpreted them as produced by decapod brachyuran or astaciid crustaceans. On the basis of the lithologies of the beds in which they have been recognized, we postulate that the animals lived either in a shallow subaqueous environment, as corroborated by their occurrence within lenticular gypsum deposits, or in humid, at least periodically flooded areas (marlstones with intrasedimentary gypsum characteristic of shallow vadose to phreatic conditions). Both facies are indicative of moderately high salinities which is in agreement with the fact that coleopterans and annelids are adapted to saline aqueous environments. Gerdes et al. (1985); Hammer (1986) and Williams et al. (1990) point out that annelids tolerate salinities up to $70 \mathrm{~g} / \mathrm{l}$ whereas coleopterans can be adapted normally to salinities up to $140 \mathrm{~g} / \mathrm{l}$, though a few species live in brines up to $250 \mathrm{~g} / \mathrm{l}$.

\subsection{Type 5: L-shaped traces}

\subsubsection{Description}

The L shape results from the combination of shafts and tunnels forming an angle of about $90^{\circ}$ (Fig. 5C). The contact between the tubes and the host rock is rather sharp. No external ornamentation of the walls is recognized. The length of the intervening branches varies from 3 to $7 \mathrm{~cm}$, being commonly the same in each trace. Diameters range from 0.5 to 3 $\mathrm{cm}$ with more frequent values around from 1 to 2 $\mathrm{cm}$. The horizontal tubes (tunnels) are often flattened because of compaction of the sediment. The trace infill is massive, usually comprising gypsum cement formed of anhedral gypsum crystals. In a very few cases, the burrows show partial meniscate infill. The L-shaped traces occur in gypsiferous mudstone and greenish white marl containing gypsum lenses.

\subsubsection{Interpretation}

The trace represents dwelling structures of invertebrate animals, likely arthropods such as coleopter- ans (Chamberlain, 1975; Frey and Pemberton, 1984). Similar traces have been also described by Smith and Hein (1971) and Retallack (1990), who point out that the traces are more abundant in subaerial environments. The abundance of coleopterans in recent saline lakes has been pointed out by Vives and Vives (1978) and Gerdes et al. (1985).

\subsection{Type 6: vertebrate tracks}

\subsubsection{Description}

Two types of vertebrate tracks have been recognized on bed surfaces of gypsiferous marls and gypsum deposits: (1) tracks consisting of the imprint of four fingers reaching in total $2 \mathrm{~cm}$ in length (Fig. 6D); (2) depressions with a rather circular geometry, 5-6 cm in diameter and $1 \mathrm{~cm}$ in depth. They do not show clear finger forms or other clear anatomic features.

\subsubsection{Interpretation}

The first type of track seems to correspond to a hyaenid of small size whereas the circular tracks could be related to prints of paws or hoofs covered by mud (J. Morales and L. Alcalá, pers. commun., 1992). Truc (1978) described similar trails of mammals, which he attributed to Palaeotherium, in the Eocene of the Mormoiron Basin, southwestern France.

\section{Sedimentological and palaeoenvironmental significance of trace fossils in the evaporite sequences}

The sedimentological analysis of the evaporite formations present in Tertiary continental basins of Spain allows definition of the typical facies associations in which the trace fossils occur. Most of these facies associations show a marked sequential arrangement (Fig. 6). Overall, the sandstone, carbonate and evaporite deposits were accumulated in mudflatsaline lake complexes (Hardie et al., 1978; Eugster and Kelts, 1983; Smoot and Lowestein, 1991). The combined analysis of lithofacies and trace fossils in these deposits delineates distinct subenvironments and provides evidence of the importance of floral and faunal activity in such an evaporitic setting.

The transition from mudflat to hypersaline lakes 


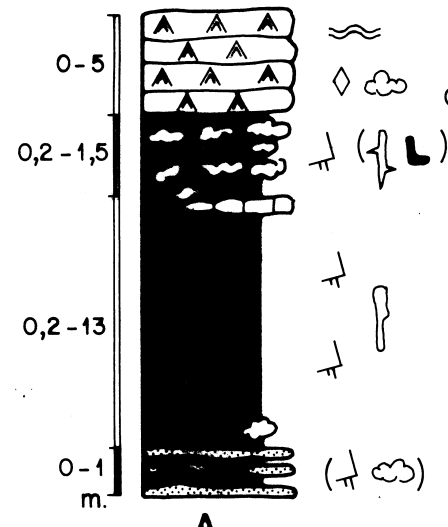

A

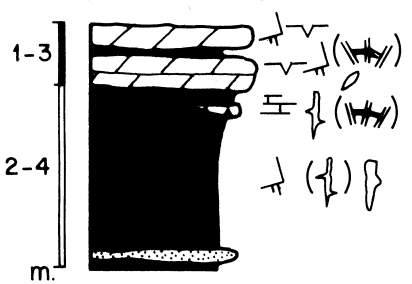

B

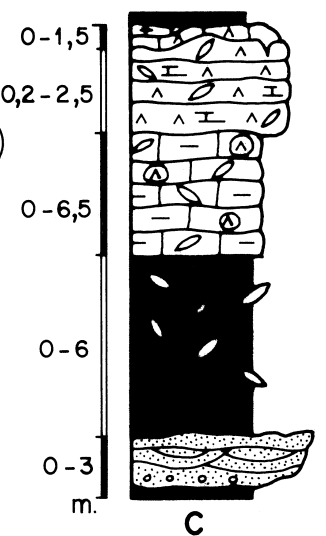

$\{4$

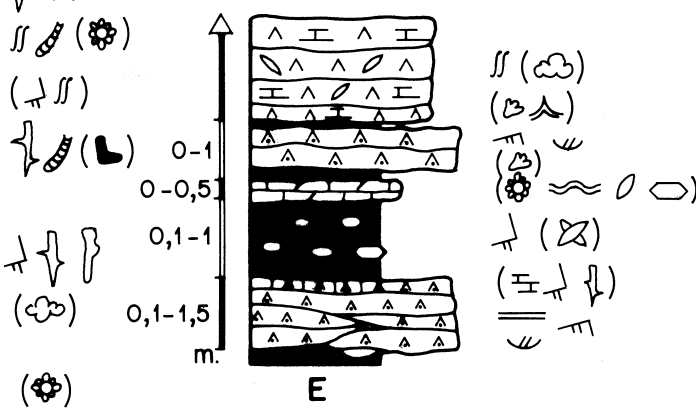

C
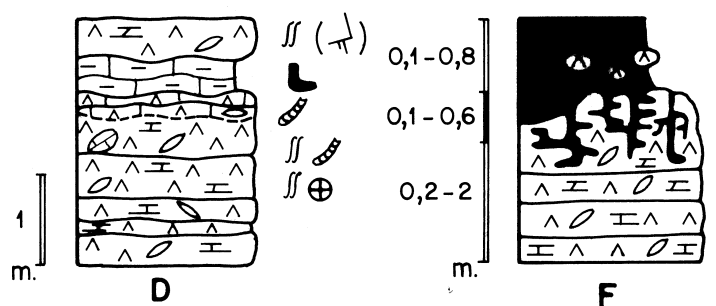

$(\pi\{\})(m)$
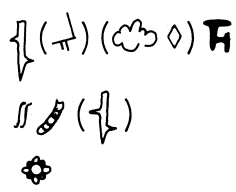

$F$

TRACE FOSSIL TYPES

\begin{tabular}{|c|c|}
\hline & SANDSTONE \\
\hline & MUDSTONE \\
\hline & LIMESTONE \\
\hline ए马 & DOLOSTONE \\
\hline$\wedge \wedge$ & $\begin{array}{l}\text { PRIMARY } \\
\text { GYPSUM }\end{array}$ \\
\hline$\Delta A$ & $\begin{array}{l}\text { DETRITAL } \\
\text { GYPSUM }\end{array}$ \\
\hline & $\begin{array}{l}\text { SECONDARY } \\
\text { GYPSUM }\end{array}$ \\
\hline
\end{tabular}

$0 \underset{\text { GYNPSUM }}{\text { LENAR }}$

28 GYPSUM

$\bigoplus$ SILICIFICATION NI CURRENT-

$\checkmark$ GEMIPYRAMIDAL

$\|=\|$ BOX-WORK

今 WAVE RIPPLES

1. GRASS ROOTS

$\{$ 2. BUSH ROOTS

$\checkmark$ glauberite $T$ Palaeo-kars

$\diamond$ GLAUBERITE

(A) GYPSUM

m ANHYDRITE

F PAFICATION

(1) ROOT MOTTLED

- charophrtes

$\iint$ 3. TANGLE-PATTERNED BURROWS

$\&$ 4. LARGE ISOLATED BURROWS

5. L-SHAPED tRACES

3 6. VERTEBRATE TRACKS

Fig. 6. Measured logs of the main representative sedimentary cycles recognized in continental evaporite formations in Spain, with indication of the types of trace fossils present in them. See explanation in the text.

is commonly marked by lateral grading of tabular, medium- to fine-grained sandstone beds into red or green mudstone with nodular anhydrite, locally developed carbonate pond beds (Sanz et al., 1995) and bedded gypsum deposits which usually resulted from replacement of more soluble salts (halite, anhydrite, Na-sulfates). These facies are commonly arranged in normal sedimentary cycles such as that drawn in Fig. 6A, although inverse sequential arrangement has been locally recognized. Trace fossils are represented in the sequence mainly in the form of rhizoliths, with predominance of those related to grass roots (type 1 ). Mottling of the red mudstones can also be interpreted as related to roots (Wright, 1989). Besides rhizoliths, L-shaped traces are present locally in the red mudstones containing anhydrite nodules below the bedded gypsum. Bioturbation related to roots is a rather common feature in mudflats of recent saline lake environments (Hammer, 1986). In these cases, vegetation adapted to moderately to high saline conditions is able to grow by taking advantage of the supply of groundwater and episodic periods of flooding in the basins. Besides, the presence of organic matter associated with roots could account for the formation of intrasedimentary anhydrite nodules in the mudstones (Cody and Hull, 1980).

Mudflat areas hosting ephemeral carbonate ponds (Sanz et al., 1995) constitute a very appropriate en- 
vironment for the development of an extensive vegetation cover. Both small and large rhizoliths, commonly accompanied by widespread mottling, are recognized within reddish mudstones of the dry mudflats. Progressive flooding and the further installation of a relatively diluted water body is also accompanied by the development of networks of rhizoliths, usually included in dolomicrites at the top of the cycles (Fig. 6B; Sanz et al., 1995). We postulate that the concentration of water in the ponds must be moderate as most of the grasses living in evaporite environments, with the exception of a few species like Ruppia, rarely support salinities higher than $60 \mathrm{~g} / \mathrm{l}$ (Hammer, 1986).

A variation of the facies arrangement typical of the transition from the mudflat to saline lake is observed in basins where highly efficient, stream-dominated alluvial fans (Nilsen, 1982) reached the basin area. In this setting, cycles as that represented in Fig. 6C formed. The sedimentary cycle reflects rather rapid transition from sandflats fed by ephemeral streams to saline mudflats consisting of red mudstone with abundant intrasedimentary gypsum and then to saline lake gypsum deposits with variable amount of carbonate. Rhizoliths and pervasive mottling are present within the mudflat facies. Networks of rhizoliths are also locally present in lake deposits suggesting that they underwent episodic subaerial exposure or the water level was extremely shallow and relatively diluted. The lacustrine deposits may be in turn divided into two distinctive horizons: a lower horizon made of carbonate marls with abundant intrasedimentary lenticular gypsum and scarce gypsum nodules, and an upper horizon comprising massive lenticular gypsum beds with local intercalations of charophyte biomicrites and pelloidal micrites, both of them containing gypsum lenses. The latter facies is sometimes capped by carbonates, owing probably to replacement of gypsum, that show palaeokarstification features. Large rhizoliths, L-shaped traces and large isolated burrows are common in the carbonate marls whereas the lenticular gypsum deposits exhibit strong bioturbation in the form of tangle-patterned small burrows. This distribution of the trace fossils within the lake sediments is in agreement with the salinity tolerance of the different groups of organisms that we have interpreted as the tracemakers. Thus, larvae of chironomids can live in saline waters whose range of salinity varies from 70 to $170 \mathrm{~g} / \mathrm{l}$ (Paterson and Walker,
1974; Hammer, 1986). By contrast, most of aquatic coleopterans and aquatic annelids rarely live at salinities higher than $40 \mathrm{~g} / \mathrm{l}$, except for a few species that can tolerate 180 and $70 \mathrm{~g} / \mathrm{l}$, respectively (Gerdes et al., 1985; Hammer, 1986). This assessment fits well the fact that chironomid larvae proliferated in more concentrated saline waters leading to extensive burrowing of the gypsum deposited in them.

As indicated above, there are several examples of Tertiary continental basins in Spain, for instance the Teruel basin and several widespread formations of the Duero and Madrid basins, where the saline lake systems were exclusively formed of gypsum. Sediments accumulated in the central parts of these lake systems typically consist of stacked gypsum and marl units as shown in Fig. 6D. Successions of stacked gypsum and marls up to $100 \mathrm{~m}$ thick have been measured in some basins. Both gypsum (predominant) and marl fabrics are similar to those described for the upper part of the sequence shown in Fig. 6C and similar is also the overwhelming abundance of the tangle-patterned small burrows within the gypsum beds. The presence of these trace fossils presumed to be the work of insect larvae (chironomids) would be also indicative of moderately high salinities (up to $170 \mathrm{~g} / \mathrm{l}$ ), quite consistent with concentration values required for gypsum precipitation after continental brines, which is lower than that required for precipitation of gypsum from marine waters (Ortí et al., 1984). Marl intercalations within the sequences are indicative of periods of relative brine dilution in which arthropods, mainly coleopterans could develop. Silicification replacement is a common process recognized in the saline lake facies (Arribas et al., 1991; Salvany et al., 1994).

Detrital gypsum is a rather common component of many evaporite formations in the analysed basins. The detrital gypsum deposits occur in association with greenish mudstone with intrasedimentary gypsum, chemically precipitated gypsum and gypsiferous carbonate with local stromatolite fabrics (Fig. 6E). This facies association is interpreted as characteristic of the transition from saline mudflats to the saline lakes in some sides of the basins (Sanz et al., 1994; Rodríguez-Aranda, 1995). Thus, the cycles characterize lake margin subenvironments. In this setting, trace fossils are mainly represented by networks of rhizoliths and less common large root 


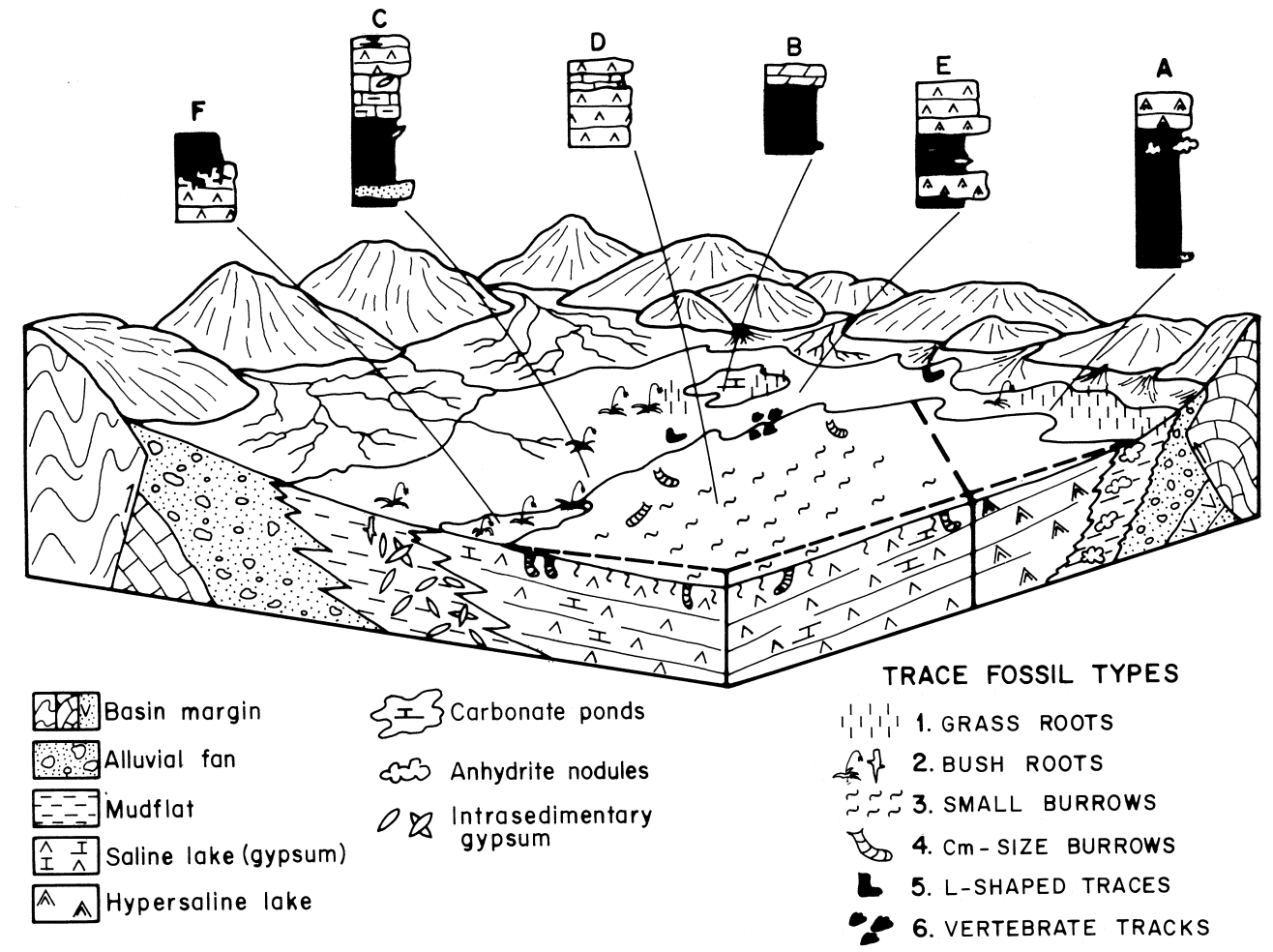

Fig. 7. Idealised model for the distribution of the various trace fossil types distinguished in the evaporite continental formations. The sketch includes location of the sedimentary cycles (drawn in Fig. 6) related to the individual saline lake subenvironments. Figure not to scale.

casts indicative of well developed vegetation covers in periods of reduced sediment accumulation. In addition to the roots, some vertebrate tracks made by mammals record the life activity of other organisms that were related to water availability.

Drastic variation in palaeoenvironmental conditions is recorded by the combined change of trace fossils and lithofacies at the top of some evaporite sequences (Fig. 6F). This facies association reflects marked dilution stages through the sedimentary evolution of the saline lakes. The gypsum beds typically display burrowing (types 3 and 4) but their tops are also affected by well-developed root bioturbation indicative of periods of net subaerial exposure. The prolongated exposure of the gypsum lake beds is underlined by karstification features as well as by the presence of early diagenetic fabrics. Usually, conduits related to karst dissolution follow and enlarge the root holes. Besides these features, lo- cal secondary gypsum fabrics, some after anhydrite, towards the top of the gypsum beds may also be interpreted as a result of plant activity and formation of gypsum crusts, similar to those described by Gunatilaka (1990) from recent coastal sabkhas.

An idealized sedimentary model showing the different saline lake subenvironments is represented in Fig. 7. In this scheme we indicate the location of the several evaporite sequences described above which would result mostly from the progressive expansion of the saline lake. The distribution of various types of trace fossils in the lake subenvironments is discussed below.

\section{Discussion}

Trace fossils have been scarcely used as palaeoenvironmental indicators in continental, typically 
closed evaporite basins. Gierlowsky-Kordesh and Rust (1994) pointed out reasonably that high salinity of lake waters can exclude a burrowing invertebrate fauna. Sharing basically this assessment, we provide evidence in this paper that moderately high salinities, i.e. 100-150 g/l, permit a wide development of fauna and flora whose bioturbation effects can be recorded in the lake sediments.

Recognition of trace fossils and rhizoliths in evaporite facies of several Tertiary basins in Spain lead us to the conclusion that both the development and distribution of the various types of traces were mainly dependent of brine concentration, hydrological regimes and sedimentation rates in the individual lake subenvironments. Thus, halophilic grasses and other halophilic plants able to germinate and grow fast after episodic floodings could develop on mudflats where displacive anhydrite nodules formed. Likewise, grasses constituted the main vegetation cover in ephemeral carbonate ponds developed on the mudflats (Fig. 7). On the other hand, bushes of halophilic plants colonized the mudflat areas in association with gypsum deposits after desiccation of the saline lakes, suggesting that they were resistant enough to root in calcium sulfate-rich grounds. Thus, the relative abundance of grass roots versus bush roots could be used as an indicator of higher saline conditions in the mudflat subenvironment.

Trace fossils caused by burrowing invertebrate fauna are typical of the saline lake subenvironments. As deduced from their location in the sequences, the various types of trace fossils appear to characterize distinct enviromental conditions. Tangle-patterned small burrows are typically found in lacustrine gypsum facies indicative of stable, moderately high salinity of lake water. Extensive burrowing by insect, probably chironomid, larvae was coeval with the deposition of gypsum in shallow, non-stratified saline lakes under oxidising conditions which prevented preservation of organic matter. The presence of nutrients derived from probable high productivity in the lake waters (Burne and Ferguson, 1983) is, however, deducible from the widespread occurrence of bioturbation as well as from the influence of organic matter in controlling the lenticular gypsum habits (Cody and Cody, 1988). Further assessment on the influence of other factors such as temperature, redox conditions, presence of predators or competi- tion among other species (Williams et al., 1990) is beyond the scope of this work.

In contrast with the relatively concentrated brines characterized by the presence of tangle-patterned small burrows, the isolated large burrows and Lshaped traces, interpreted to have been mainly caused by arthropods, mostly coleopterans, are found in marginal lake deposits as well as gypsiferous marlstone interbedded with lenticular gypsum. Both occurrences indicate that the latter traces could be formed only in areas where the brines did not reach high concentration or in periods of relatively dilution of the saline lake waters. Finally, recognition of vertebrate tracks does not seem to be significant for palaeoenvironmental reconstruction excepts for the fact they commonly occur in association with marginal lake deposits.

Some final comments concern the relationships between bioturbation and the depositional fabrics of the sediments in which burrowing and root bioturbation occurs and its influence on the diagenetic features observed in the sediments. This is particularly outstanding in the bioturbated gypsum deposits where mixing of sediment by bioturbation has destroyed any primary orientation of the gypsum lenses. An additional aspect is the contribution of faecal pellets into the sediment as a result of the extensive organic activity. The diagenetic features observed in this gypsum facies as well as in other deposits affected by bioturbation are also very specific as the traces produce significative changes in the primary porosity and permeability of the sediments and controlled distribution of the organic matter, for instance mucus, within the deposits (Fisher, 1982). As a result, distinctive replacements by silica or anhydrite, gypsum cementation, and calcititation that mimic the burrow fabrics are observed in the cycles, thus making easier the recognition of trace fossils. In some cases, however, the diagenetic features erase partially or totally the original burrowed fabrics.

\section{Conclusions}

Six main types of trace fossils and rhizoliths have been distinguished from evaporite formations of continental Tertiary basins of Spain. The trace fossils were caused mainly by organic activity of plants (pe- 
doturbation) and invertebrate fauna bioturbation. Locally, some vertebrate tracks have been recognized. The trace fossils occur in sediments accumulated in mudflat-saline lake complexes. Most impressive burrowing by invertebrate fauna (insect larvae, probably chironomids, annelids and coleopterans) is present in thick, massive gypsum beds and intercalated gypsiferous marls. The combined analysis of these lithofacies and included trace fossils allows us to conclude that they formed in lake waters of moderately high salinities ranging 100-150 g/l which are typical values for gypsum precipitation in saline continental waters. Consequently, this study highlights the relevance of trace fossils, at least under these specific conditions, for palaeoenvironmental analysis in ancient continental evaporite sequences.

\section{Acknowledgements}

We thank Dr. E. Sanz, A.M. Alonso Zarza, J.M. Rouchy, T. Torres and A. Soriano for their comments on this paper. We are grateful to the journal referees Dr. R.G. Bromley and an anonymous referee for their constructive criticism of the manuscript. The investigation of bioturbated gypsum deposits in Tertiary basins of Spain was greatly inspired by field-work organized by the IGCP-324 Project-Spanish Group since the late eighties. We are indebted to J. Sánchez and J. Arroyo for their technical assistance. This work has been supported by Projects PB 920013 and AMB 94-0094, financed by DGICYT and CICYT, respectively.

\section{References}

Alonso-Zarza, A.M., Calvo, J.P., García del Cura, M.A., 1992. Palustrine sedimentation and associated features - grainification and pseudo-microkarstification in the Middle Miocene (Intermediate Unit) of the Madrid Basin. Sediment. Geol. 76, 43-62.

Anadón, P., 1989. Los lagos salinos interiores (atalásicos) con faunas de afinidad marina del Cenozoico de la Península Ibérica. Acta Geol. Hisp. 24, 83-102.

Anadón, P., Zamarreño, I., 1981. Paleogene nonmarine algal deposits of the Ebro Basin, Northeastern Spain. In: Monty, C. (Ed.), Phanerozoic Stromatolites. Springer, Berlin, pp. 140 154.

Anadón, P., Cabrera, L., Julia, R., Roca, E., Rosell, L., 1989.
Lacustrine oil-shale basins in Tertiary grabens from NE Spain (Western European Rift system). Palaeogeogr., Palaeoclimatol., Palaeoecol. 70, 7-28.

Anadón, P., Ortí, F., Rosell, L., 1995. Unidades evaporiticas de la zona de Libros-Cascante (Mioceno, Cuenca de Teruel): características sedimentoló gicas. XIII Congr. Español Sediment., Teruel, Com., pp. 135-136.

Armenteros, I., Dabrio, C.J., Alonso Gavilan, G., Jorquera, A., Villalobos, M., 1986. Laminación y bioturbación en carbonatos lagunares: Interpretación genética (Cuenca del Guadiana, Badajoz). Estud. Geol. 42, 271-280.

Arribas, J., Bustillo, M.A., Díaz Molina, M., 1991. Chert bioturbated sediments of sabkha paleoenvironment. VI Flint Int. Symp., Madrid, pp. 29-33 (abstract).

Bauld, J., 1986. Benthic microbial communities of Australian saline lakes. In: De Decker, P., Williams, W. (Eds.), Limnology in Australia. CSIRO, Melbourne, pp. 95-111.

Bromley, R.G., 1996. Trace Fossils. Biology and Taphonomy, 2nd ed. Unwin Hyman, London, 280 pp.

Bromley, R.G., Asgaard, U., 1979. Ichnofacies: a mixture of taphofacies and biofacies. Lethaia 24, 153-163.

Buatois, L.A., Mangano, M.G., 1995. The paleoenvironmental and paleoecological significance of the lacustrine Mermia ichnofacies: an archetypical subaqueous nonmarine trace fossil assemblage. Ichnos 4, 1-12.

Burne, R.V., Ferguson, J., 1983. Contrasting marginal sediments of a seasonally flooded saline lake-Lake Eliza, south Australia. Significance for oil-shale genesis. B.M.R. J. Aust. Geol. Geophys. 8, 99-108.

Burne, R.V., Bauld, J., De Deckker, P., 1980. Saline lake charophytes and their geological significance. J. Sediment. Petrol. 50, 281-293.

Calvo, J.F., Iborra, J., 1986. Estudio ecólogico de la Laguna de La Mata. Ins. Estudios Juan Gil-Albert, Dip. Prov., Alicante, $101 \mathrm{pp}$.

Calvo, J.P., Alonso Zarza, A.M., García del Cura, M.A., 1989. Models of Miocene marginal lacustrine sedimentation in response to varied depositional regimes and source areas in the Madrid Basin (Central Spain). Palaeogeogr., Palaeoclimatol., Palaeoecol. 70, 199-214.

Chamberlain, C.K., 1975. Recent lebensspuren in non marine aquatic environments. In: Frey, R.W. (Ed.), The Study of Trace Fossils. Springer, Berlin, pp. 431-458.

Chivas, A., De Decker, P., Shelley, J.M.G., 1986. Magnesium and the strontium in nonmarine ostracode shells as indicators of paleosalinity and paleotemperature. Hydrobiologia 143, 135142.

Cody, R.D., Cody, A.M., 1988. Gypsum nucleation and crystal morphology in analog saline terrestrial environments. J. Sediment. Petrol. 58, 247-255.

Cody, R.D., Hull, A.B., 1980. Experimental growth of primary anhydrite at low temperatures and water salinities. Geology 8, 505-509.

Cohen, A., 1982. Paleoenvironments of root casts from the Koobi Fora Formation, Kenya. J. Sediment. Petrol. 52, 401-414.

Corrochano, A., Armenteros, I., 1989. Los sistemas lacustres de la Cuenca Terciaria del Duero. In: Anadón, P., Cabrera, L. 
(Eds.), Sistemas Lacustres Cenozoicos en España. Acta Geol. Hisp. 24, 259-279.

D’Alessandro, A., Bromley, R.G., 1987. Meniscate trace fossils and the Muensteria-Taerudium problem. Palaeontology 30, 743-776.

De Deckker, P., 1988. Biological and sedimentary facies of Australian salt lakes. Palaeogeogr., Palaeoclimatol., Palaeoecol. 62, 237-270.

Ekdale, A.A., Bromley, R.G., Pemberton, S.G., 1984. Ichnology: trace fossils in sedimentology and stratigraphy. Soc. Econ. Paleontol. Mineral. Short Course 15, 317 pp.

Eugster, H.P., Kelts, K., 1983. Lacustrine chemical sediments. In: Goudie, A.S., Pye, K. (Eds.), Chemical Sediments and Geomorphology. Academic Press, London, pp. 321-368.

Evenary, M., Gutterman, Y., Gavish, E., 1985. Botanical studies of coastal salines and sabkhas of the Sinai. In: Friedman, G.M., Krumbein, W.E. (Eds.), Hypersaline Ecosystems. The Gavish Sabkha. Springer, Berlin, pp. 145-182.

Fisher, J.B., 1982. Effects of macrobenthos on the chemical diagenesis of freshwater sediments. In: McCall, P.L., Tevesz, M.J.S. (Eds.), Animal-Sediment Relations. Plenum Press, New York, NY, pp. 177-217.

Frey, R.W., Pemberton, S.G., 1984. Trace fossil facies models. In: WaLker, R.G. (Ed.), Facies Models. Geosci. Can. Reprint Ser. 1, 189-207.

Friedman, G.M., Krumbein, W.E. (Eds.), 1985. Hypersaline Ecosystems. The Gavish Sabkha. Springer, Berlin, 484 pp.

Friend, P., Dabrio, C. (Eds.), 1996. Tertiary Iberian Basins. World and Regional Series. Cambridge Univ. Press, 400 pp.

García Ramos, J.C., Valenzuela, M., Suarez de Centi, C., 1989. Sedimentología de las huellas de actividad orgánica. In: Arche, A. (Coord.), Sedimentología, Vol. 2. C.S.I.C. Nuevas Tendencias, Madrid, pp. 261-342.

Gerdes, G., Spira, J., Dimentman, C., 1985. The fauna of the Gavish Sabkha and the Solar Lake - a comparative study. In: Friedman, G.M., Krumbein, W. (Eds.), Hypersaline Ecosystems. The Gavish Sabkha. Springer, Berlin, pp. 322-345.

Gierlowski-Kordesch, E., 1991. Ichnology of an ephemeral lacustrine/alluvial plain system: Jurassic East Berlin Formation, Hartford Basin, USA. Ichnos 1, 221-232.

Gierlowski-Kordesch, E., Rust, B.R., 1994. The Jurassic East Berlin Formation, Hartford Basin, Newark Supergroup (Connecticut and Massachusetts): a saline lake-playa-alluvial plain system. In: Renaut, R.W., Last, W.M. (Eds.), Sedimentology and Geochemistry of Modern and Ancient Saline Lakes. SEPM Spec. Publ. 50, 249-266.

Gunatilaka, A., 1990. Anhydrite diagenesis in a vegetated sabkha, Al-Khiram, Kuwait, Arabian Gulf. Sediment. Geol. 69, 95-116.

Hammer, U.T., 1986. Saline Lake Ecosystems of the World. Junk, Dordrecht, 616 pp.

Hardie, L., Smoot, J.P., Eugster, H.P., 1978. Saline lakes and their deposits: a sedimentological approach. In: Matter, A., Tucker, M. (Eds.), Modern and Ancient Lake Sediments. Spec. Publ. Int. Assoc. Sedimentol. 2, 7-41.

Klappa, C.F., 1980. Rhizoliths in terrestial carbonates: classifica- tion, recognition, genesis and significance. Sedimentology 27, 613-629.

Last, W.M., 1989. Continental brines and evaporites of the northern Great Plains of Canada. Sediment. Geol. 64, 207-222.

Magee, J.W., 1991. Late Quaternary lacustrine, ground water, aeolian end pedogenic gypsum in the Prungle Lake, southeastern Australia. Palaeogeogr., Palaeoclimatol., Palaeoecol. 84, 342.

McCall, P.L., Tevesz, M.J.S., 1982. The effects of benthos in physical properties of freshwater sediments. In: McCall, P.L., Tevesz, M.J.S. (Eds.), Animal-Sediment Relations. Plenum Press, New York, NY, pp. 105-176.

Mediavilla, R., 1986. Sedimentología de los yesos del sector central de la Depresión del Duero. Acta Geol. Hisp. 21-22, 35-44.

Montes, C., Martino, P., 1987. Las lagunas salinas espanolas. Sem. Proteccion Humedales de España, Real Acad. CC. Exactas, Fis. Nat., Madrid, pp. 95-145.

Monty, C.L.V., 1976. The origin and development of cryptalgal fabrics. In: Walter, M.R. (Ed.), Stromatolites. Elsevier, Amsterdam, pp. 193-249.

Nilsen, T.H., 1982. Alluvial fan deposits. In: Scholle, P.A., Spearing, D. (Eds.), Sandstone Depositional Environments. A.A.P.G. Mem. 31, 49-86.

Oliver, D.R., 1971. Life history of the Chironomidae. Annu. Rev. Entomol. 16, 211-230.

Ortí, F., 1987. La zona de Villel-Cascante-Javalambre. Introduccion a las formaciones evaporíticas y al volcanismo jurásico. XXI Curso Geol. Pract. Teruel, pp. 56-95.

Ortí, F., Salvany, J.M. (Eds.), 1990. Formaciones evaporíticas de la Cuenca del Ebro y Cadenas perifericas y de la zona de Levante. ENRESA, Barcelona, 306 pp.

Ortí, F., Pueyo, J.J., Geisler, D., Dulau, N., 1984. Evaporitic sedimentation in the coastal salines of Santa Pola (Alicante, Spain). Rev. Ins. Inv. Geol. Univ. Barcelona 38-39, 169-220.

Palacios-Fest, M.R., Cohen, A.S., Anadó n, P., 1994. Use of ostracodes as paleoenvironmental tools in the interpretation of ancient lacustrine records. Rev. Esp. Paleontol. 9, 145-164.

Paterson, C.G., Walker, K.F., 1974. Recent history of Tanytarsus barbitarsis Freeman (Diptera: Chironomidae) in the sediments of a shallow, saline lake. Aust. J. Mar. Freshwater Resour. 2, 315-325.

Playa, E., 1995. Petrología y geoquímica de elementos traza de las evaporitas de las cuencas neogenas de Fortuna y ArchenaMula (Murcia). XIII Congr. Espanol Sediment. Teruel Comun., pp. 103-104.

Plaziat, J.C., 1989. Signification ecologique et paleogeographique des peuplements oligotypiques de Potamides gasteropodes thalassiques. Atti 3rd Symp. Ecol. Paleoecol. Com. Benthon., Catania, pp. 25-52.

Pemberton, S.G., MacEachern, J.A., Frey, R.V., 1992. Trace fossil facies models: environmental and allostratigraphic significance. In: Walker, R.G., James, N.P. (Eds.), Facies Models in Response to Sea Level Change. Geol. Assoc. Can., pp. 4772.

Pueyo, J.J., 1991. Depósitos evaporíticos actuales del litoral Mediterraneo de la Península Ibérica. In: Pueyo, J.J. (Co- 
ord.), Genesis de formaciones evaporíticas. Modelos andinos e ibericos. Publ. Univ. Barcelona, pp. 136-147.

Retallack, G.J., 1990. Soils of the Past. An Introduction to Paleopedology. Unwin Hyman, Boston, 520 pp.

Rodríguez-Aranda, J.P., 1992. Significado de bioturbaciones en un medio evaporítico/continental (Mioceno de la Cuenca de Madrid). Geogaceta 12, 113-115.

Rodríguez-Aranda, J.P., 1995. Sedimentología de los sistemas de llanura lutitica-lago salino del Mioceno en la zone oriental de la Cuenca de Madrid. Ph.D. Thesis, Univ. Complutense, Madrid, 474 pp. (unpubl.).

Rodríguez-Aranda, J.P., Calvo, J.P., Sanz-Montero, E., 1996. Paleokarstificacion en facies yesiferas e implicaciones sedimentarias. Ejemplos del Mioceno de la Cuenca de Madrid. Geogaceta 20, 327-330.

Rouchy, J.M., Bernet-Rollande, M.C., Maurin, A.F., 1986. Petrographie descriptive des evaporites. Applications sur terrain en subsurface et au laboratoire. In: Les series a evaporites en exploration petroliere. Tome 1: Methodes geologiques. Technip, Paris, pp. 73-121.

Salvany, J.M., Munoz, A., Perez, A., 1994. Nonmarine evaporitic sedimentation and associated diagenetic processes of the southwestern margin of the Ebro Basin (lower Miocene), Spain. J. Sediment. Res. 64, 190-203.

Sanz, M.E., Rodríguez-Aranda, J.P., Calvo, J.P., Ordóñez, S., 1994. Tertiary detrital gypsum in the Madrid Basin, Spain: criteria for interpreting detrital gypsum in continental evaporite sequences. In: Renaut, R.W., Last, W.M. (Eds.), Sedimentology and Geochemistry of Modern and Ancient Saline Lakes. SEPM Spec. Publ. 50, 217-228.

Sanz, M.E., Alonso, A.M., Calvo, J.P., 1995. Carbonate pond deposits related to semi-arid alluvial systems. Examples from the Tertiary Madrid Basin, Spain. Sedimentology 42, 437452.

Sarjeant, W.A.S., 1975. Plant trace fossils. In: Prey, R.W. (Ed.), The Study of Trace Fossils. Springer, Berlin, pp. 163-180.

Simpson, S., 1975. Classification of trace fossils. In: Frey, R.W. (Ed.), The study of Trace Fossils. Springer, Berlin, pp. 39-54.

Smith, N.D., Hein, F.J., 1971. Biogenic reworking of fluvial sediments by Staphylinid beetles. J. Sediment. Petrol. 41, 598-602.

Smoot, J.P., Lowestein, T.K., 1991. Depositional environments of nonmarine evaporites. In: Melvin, J.L. (Ed.), Evaporites, Petroleum and Mineral Resources. Dev. Sedimentol. 50, 189-
347.

Spencer, R.J., 1982. The geochemical evolution of Great Salt Lake. Ph.D. Thesis, The Johns Hopkins Univ., Baltimore, 308 pp. (unpubl.).

Tevesz, M.J.S., McCall, P.L., 1982. Geological significance of aquatic nonmarine trace fossils. In: McCall, P.L., Tevesz, M.J.S. (Eds.), Animal-Sediment Relations. Plenum Press, New York, NY, pp. 257-285.

Thienemann, A., 1954. Chironomus. Leben, Verbreitung und wirtschaftliche Bedeutung der Chironomiden. Schweizerbart, Stuttgart, 823 pp.

Torres, T., Zapata, J.L., 1986. Caracterizacíon de dos sistemas de abanicos aluviales humedos en el Terciario de la Depresion Intermedia (Cuenca-Guadalajara). Acta Geol. Hisp. 21-22, 45-53.

Truc, G., 1978. Lacustrine sedimentation in an evaporite environment: the Ludian (Palaeogene) of the Mormoiron basin, southeastern France. In: Matter, A., Tucker, M. (Eds.), Modern and Ancient Lake Sediments. Spec. Publ. Int. Assoc. Sedimentol. 2, 189-203.

Truc, G., 1980. Evaporites in a subsident continental basin (Ludian and Stampian of Mormoiron-Pernez in Sutheastern France). Sequential aspects of deposition of primary facies and their diagenetic evolution. In: Evaporite Deposits. Technip, Paris, pp. 61-71, 234-259.

Van Dijk, D.E., Hobday, D.K., Tankard, A.J., 1978. Permo-Triassic lacustrine deposits in the Eastern Karoo Basin, Natal, South Africa. In: Matter, A., Tucker, M. (Eds.), Modern and Ancient Lake Sediments. Spec. Publ. Int. Assoc. Sedimentol. 2, 223-238.

Vives, J., Vives, E., 1978. Coleopteros halofilos de los Monegros. Boll Asoc. Esp. Entomol. 2, 205-214.

Williams, W.D., Boulton, A.J., Taaffe, R.G., 1990. Salinity as a determinant of salt lake fauna: a question of scale. Hydrobiologia 197, 257-266.

Wooton, R.J., 1988. The historical ecology of aquatic insects: an overview. Palaeogeogr., Palaeoclimatol., Palaeoecol. 62, 477492.

Wright, V.P., 1989. Geomorphic and stratigraphic relations alluvial soils: a guide for interpreting ancient paleosol-bearing sequences. In: Paleosols in siliciclastic sequences. PRIS, Reading Univ., pp. 26-48. 